Vol. 6, No. 1, 2021

\title{
TO THE PROBLEMS OF WASTEWATER TREATMENT FROM MINERAL POLLUTANTS WITH THE USE OF MICROALGAE
}

\author{
Vasil Dyachok, Solomiia Mandryk, Serhiy Huhlych \\ Lviv Polytechnic National University, \\ 12, S. Bandera Str., Lviv, 79013, Ukraine \\ dyachokvasil@gmail.com, solomiia.mandryk@ukr.net, zvit.reagent@gmail.com
}

https://doi.org/10.23939/ep2021.01.015

Received: 9.11 .2020

(C) Dyachok V., Mandryk S., Huhlych S., 2021

\begin{abstract}
This article presents the results of experimental studies on the use of Chlorella microalgae for wastewater treatment from the most common mineral pollutants. The influence of the mineral pollutants, namely anions $\mathrm{HSO}_{3}^{-}$, $\mathrm{NO}_{3}^{-}, \mathrm{H}_{2} \mathrm{PO}_{4}^{-}$on the dynamics of wastewater treatment has been established. Analytical dependences of microalgae biomass growth rate depending on pollutant concentration $\mathrm{HSO}_{3}^{-}, \mathrm{NO}_{3}^{-}$and $\mathrm{H}_{2} \mathrm{PO}_{4}^{-}$are obtained. The values of biomass growth coefficients at the corresponding pollutant concentrations are determined. Based on the obtained experimental research results, mathematical models have been constructed that allow predicting the maximum values of mineral pollutants concentrations at which effective wastewater treatment by chlorophyllsynthesizing microalgae is possible. The technological scheme of wastewater treatment from mineral pollutants and the mechanism of the obtained application biomass are proposed.
\end{abstract}

Key words: sulfur anion $\left(\mathrm{HSO}_{3}^{-}\right)$, nitrogen anion $\left(\mathrm{NO}_{3}^{-}\right)$, phosphorus anion $\left(\mathrm{H}_{2} \mathrm{PO}_{4}^{-}\right)$, Chlorella, chlorophyllsynthesizing microalgae, wastewater treatment, mineral pollutants.

\section{Introduction}

Due to the expansion of production and the imperfection of treatment technologies, environmental pollution has reached its peak. The hydrosphere is significantly affected by pollutants. Currently, the biological method of wastewater treatment is the promising one (Manakov et al., 1990). The disadvantage of biological purification methods such as activated sludge, granular sludge, biofilm is that the necessary condition is oxygen enrichment, mixing and, as a consequence, carbon dioxide evolution. The advantage of our technology is that the sorption of sulfur anion $\left(\mathrm{HSO}_{3}^{-}\right)$, nitrogen anion $\left(\mathrm{NO}_{3}^{-}\right)$, phosphorus anion $\left(\mathrm{H}_{2} \mathrm{PO}_{4}^{-}\right)$and carbon dioxide $\left(\mathrm{CO}_{2}\right)$ by Chlorella microalgae occurs with the release of oxygen as the product of photosynthesis.

The problem of the current system of biological wastewater treatment in aerotanks is the enormous cost of oxygen for the bacterial processes of organic and mineral substances removal in wastewater, and carbon dioxide $\left(\mathrm{CO}_{2}\right)$, as a product of bacteria living abilities, is released into the air. It means that the present existing treatment plants are the oxygen consumers and air pollutants with carbon dioxide $\left(\mathrm{CO}_{2}\right)$. It should also be noted that the biological feature of the bacteria is that they are narrowly specialized, that is, there is no one type of bacteria that could purify the entire spectrum of contaminants present in wastewater (Hubskyy, 2007).

The proposed technology provides a method of wastewater treatment with different concentrations of contaminants using a specific strain of microalgae. Ecologically, this is justified by the fact that microalgae consume carbon dioxide $\left(\mathrm{CO}_{2}\right)$ and release oxygen for their living abilities (Statsenko, Vynohradova, 1972). Evolutionary microalgae are at a higher level of development than bacteria, and therefore many of their species are universal consumers of many organic and mineral substances which are pollutants of wastewater.

In the burning of fuel (solid, liquid, gaseous), besides carbon dioxide, sulfur, nitrogen and phosphorus oxides are released into the air. With precipitation, these pollutants return to the hydrosphere in the form of anions

For citation: Dyachok V., Mandryk S., Huhlych S., 2020. To the problems of wastewater treatment from mineral pollutants with the use of microalgae. Journal Environmental Problems. Vol. 6, No. 1. p. 15-20. DOI: https://doi.org/10.23939/ep2021.01.015 
and cause acidification of reservoirs. Therefore, these anions were chosen for the experimental study.

The literature contains little data on the effect of anions $\mathrm{HSO}_{3}^{-}, \mathrm{NO}_{3}^{-}$and $\mathrm{H}_{2} \mathrm{PO}_{4}^{-}$on the dynamics of wastewater treatment by chlorophyllsynthesizing microalgae (Dyachok et al., 2018; Dyachok et al., 2019a). Therefore, it is important to study the influence of these anions concentrations on the dynamics of wastewater treatment.

The aim of this work is to determine critical or maximum permissible concentrations of anions $\mathrm{HSO}_{3}^{-}$, $\mathrm{NO}_{3}^{-}$and $\mathrm{H}_{2} \mathrm{PO}_{4}^{-}$in wastewater where the cultivation of the Chlorella type microalgae is possible.

\section{Theoretical part}

Using the strain of the Chlorella type microalgae a high degree of biological purification from mineral pollutants is achieved. The biomass, accumulated in this way, can be used as an organic "green" fertilizer or converted by biomethanization to methane gas (Zolotaryova et al., 2008). The use of this microalgae strain does not require reorganization or major construction of new treatment plants.

During the experimental research, culture of green microalgae - Chlorella was the object of observation. For this purpose, the culture of microalgae Chlorella was placed into wastewater containing anions $\mathrm{HSO}_{3}^{-}, \mathrm{NO}_{3}^{-}$and $\mathrm{H}_{2} \mathrm{PO}_{4}^{-}$. Nutrients - carbon dioxide and mineral nutrients elements microalgae cells obtaine directly from the environment by absorbing them with their entire surface. Since anions like $\mathrm{HSO}_{3}^{-}, \mathrm{NO}_{3}^{-}$and $\mathrm{H}_{2} \mathrm{PO}_{4}^{-}$are absorbed by microalgae, their effect on the growth of chlorophyllsynthesizing microalgae was studied at different concentration values of the corresponding anions.

To study the effect of anions $\mathrm{HSO}_{3}^{-}$on the increase of chlorophyllsynthesizing microalgae, the values of anion $\mathrm{HSO}_{3}^{-}$concentration were investigated and shown in Fig. 1. To study the effect of anion $\mathrm{NO}_{3}^{-}$ and $\mathrm{H}_{2} \mathrm{PO}_{4}^{-}$on the increase of chlorophyllsynthesizing microalgae, the values of anion concentration are shown in Fig. 3 and Fig. 5. Accordingly, the control solution, which did not contain the corresponding anions in three variants of the research, it should be also noted that the conditions of the experiment involved the presence of natural light and the temperature of $30 \pm 5^{\circ} \mathrm{C}$.

The increase in the biomass of chlorophyllsynthesizing microalgae under these conditions was determined by the photocolorimetric method using a blue light filter according to the law of Bouguer-LambertBehr (Poltorak et al., 1972). Since the optical absorption of light at a given wavelength is proportional to the concentration of microalgae, the obtained experimental data on the accumulation of microalgae biomass depending on the time within the studied concentrations of anions $\mathrm{HSO}_{3}^{-}, \mathrm{NO}_{3}^{-}$and $\mathrm{H}_{2} \mathrm{PO}_{4}^{-}$are proportional to the values of optical densities. The optical density value of the researched and control solutions was measured in relation to the reference solution. In our case, it was water.

\section{Presentation of the main material and discussion of the results}

During the experimental data processing, dependencies were obtained which illustrate the change in microalgae concentration over time at different values of anion $\mathrm{HSO}_{3}^{-}$in solution with its single introduction (Fig. 1). The obtained data indicate that presence of the anion $\mathrm{HSO}_{3}^{-}$in the wastewater significantly affects the growth of microalgae cells biomass in comparison with the control. Under the conditions of an increase in anion $\mathrm{HSO}_{3}^{-}$concentrations in wastewater, the growth of microalgae biomass decreases. In the control sample, however, its stable growth is observed. Therefore, it is appropriate to assume that the anion $\mathrm{HSO}_{3}^{-}$presence starting with concentrations of $0.001 \mathrm{mg} / \mathrm{ml}$ and more, under the conditions of the experiment, there is a suppression of the wastewater treatment process with chlorophyllsynthesizing microalgae of the Chlorella type.

A more detailed data analysis in Fig. 1 allows us to argue that the change in the number of microalgae cells per time unit under the experimental conditions is determined by the number of born and died cells. Quantitatively, this process can be described by a known equation (3), which is in the coordinates $\ln \frac{\mathrm{C}}{\mathrm{C}_{\mathrm{o}}}=\boldsymbol{f}(\mathrm{t})$, allows you to determine the growth coefficient $-\mu$ (Dyachok et al., 2017).

The growth coefficient may be $\mu>0$, under the conditions of a certain value activity of the inhibitor concentration (anion $\mathrm{HSO}_{3}^{-}$) photosynthesis can gain a negative value $\mu<0$, as well as being equal to zero. Experimental research data (Fig. 1), in coordinates $\ln \frac{\mathrm{C}}{\mathrm{C}_{\mathrm{O}}}=f(\mathrm{t})$, [Dyachok et al. 2019b] are graphically presented by the lines in Fig. 2 .

At anion $\mathrm{HSO}_{3}^{-}$concentration values in wastewater $0,001 \mathrm{mg} / \mathrm{ml} ; 0,002 \mathrm{mg} / \mathrm{ml} ; 0,003 \mathrm{mg} / \mathrm{ml} ; 0,004 \mathrm{mg} / \mathrm{ml}$, the growth rates are less than zero $\mu<0$. The numerical values of the coefficients are respectively: $\mu_{4}=-0.0563 \mathrm{~d}^{-1}$; $\mu_{5}=-0.0543 \mathrm{~d}^{-1} ; \mu_{6}=-0.0537 \mathrm{~d}^{-1} ; \mu_{7}=-0.0406 \mathrm{~d}^{-1}$. Thus, the inhibitory properties of the anion $\mathrm{HSO}_{3}^{-}$at given concentration values are obvious.

Subsequently, we studied the effect of anions $\mathrm{NO}_{3}^{-}$and $\mathrm{H}_{2} \mathrm{PO}_{4}^{-}$on the dynamics of microalgae 
growth. Based on the results of the experimental data and the calculated values, graphical dependences of the change in the concentration of microalgae cells on the time at the corresponding concentrations of anions $\mathrm{NO}_{3}^{-}$ and $\mathrm{H}_{2} \mathrm{PO}_{4}^{-}$in wastewater under the conditions of their single introduction Fig. 3 and Fig. 5 were obtained. Analyzing the data (Figs. 3, 5), it should be noted that the growth of microalgae cell biomass over time also significantly depends on the anions $\mathrm{NO}_{3}^{-}$and $\mathrm{H}_{2} \mathrm{PO}_{4}^{-}$ concentration compared to the control where anions $\mathrm{NO}_{3}^{-}$ and $\mathrm{H}_{2} \mathrm{PO}_{4}^{-}$are absent. With the increase of anions $\mathrm{NO}_{3}^{-}$ and $\mathrm{H}_{2} \mathrm{PO}_{4}^{-}$concentration, microalgae cell growth is increased compared to the control. Such an increase in the values of the microalgae concentrations, only to a certain

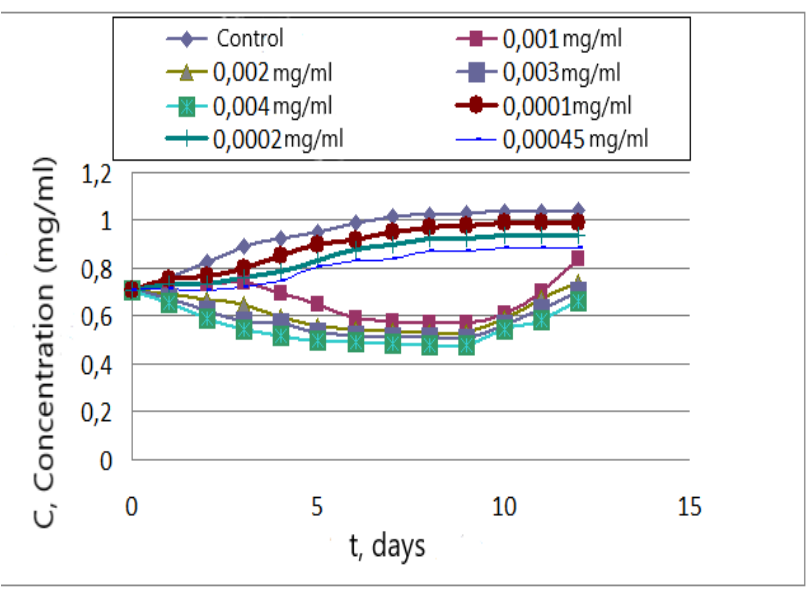

Fig. 1. The change in the concentration of microalgae cells over time at the corresponding values of anion $\mathrm{HSO}_{3}^{-}$ concentrations

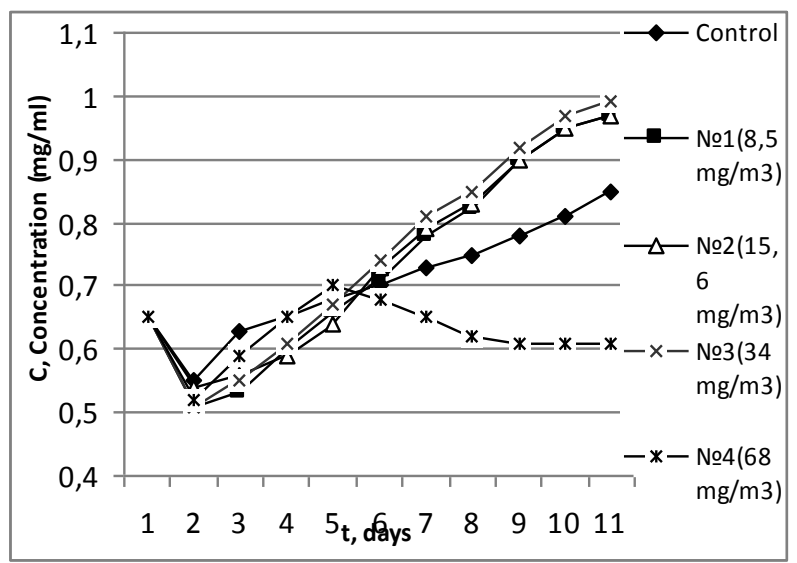

Fig. 3. The dependence of the change in the concentration of microalgae cells over time at the corresponding anion $\mathrm{NO}_{3}^{-}$ concentrations

Concerning anion $\mathrm{H}_{2} \mathrm{PO}_{4}^{-}$, a similar pattern is observed only with other concentrations. As we can see (Fig. 5), the fifth sample, where the concentration value of the concentration of the available anions $\mathrm{NO}_{3}^{-}$and $\mathrm{H}_{2} \mathrm{PO}_{4}^{-}$. As can be seen in Fig. 3, at the anion $\mathrm{NO}_{3}^{-}$concentration, $68 \mathrm{mg} / \mathrm{ml}$ (4th sample) on the second day behaves in the same way as others, it means that the adaptation phase takes place up to two days, with a slight increase starting on the third day, which is higher on the 5th day than in the control sample, but from the sixth day there is a decline and the next five days there is a decrease in growth. At higher upper values of anion $\mathrm{NO}_{3}^{-}$ concentrations, there is a dying of microalgae compared to the control.

The values of the growth coefficients - $\mu$ were found similarly, by the same methodology and they were: $0.075 \mathrm{~d}^{-1} ; 0.076 \mathrm{~d}^{-1} ; 0.077 \mathrm{~d}^{-1}$.

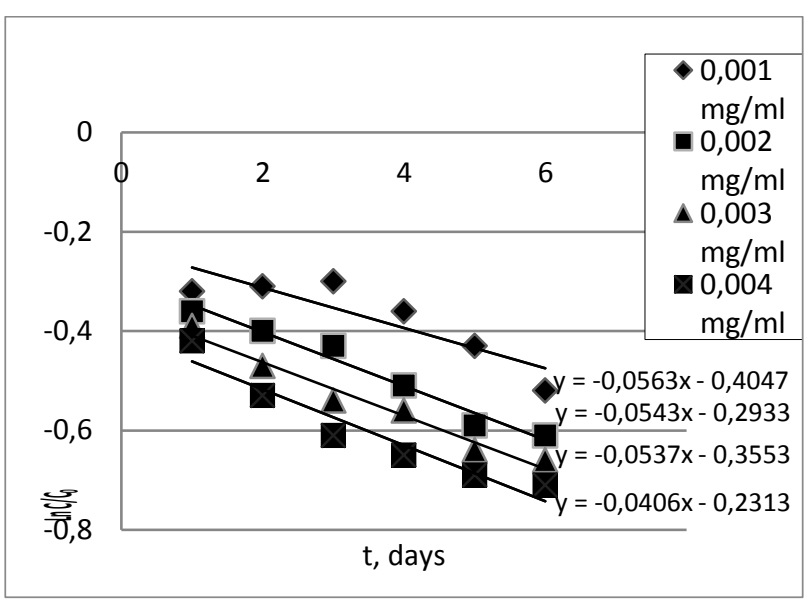

Fig. 2. The dependence of the logarithm change of the microalgae cells concentration on time at the corresponding anion $\mathrm{HSO}_{3}^{-}$concentrations

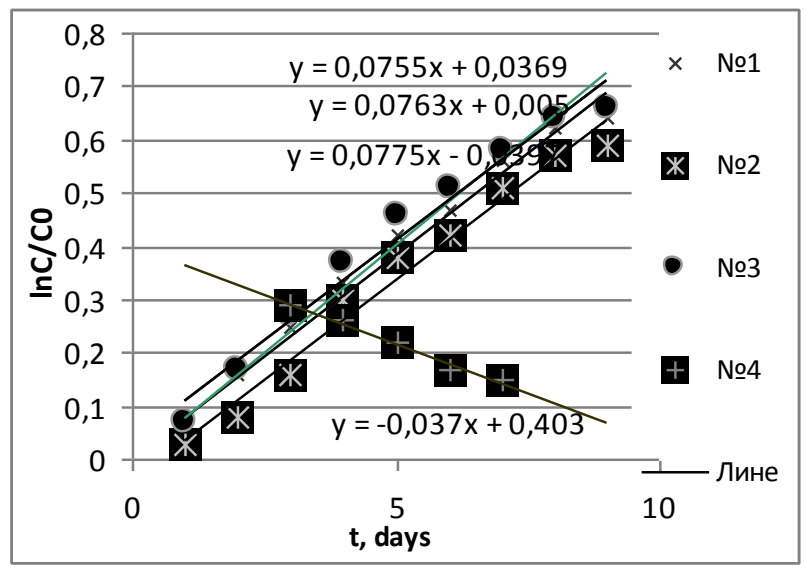

Fig. 4. Dependence of change in logarithm of suspension concentration of microalgae cell on time (at corresponding anion $\mathrm{NO}_{3}^{-}$concentrations)

is $0.1 \mathrm{mg} / \mathrm{m}^{3}$, negative growth of microalgae biomass is observed. This indicates that this concentration of anion $\mathrm{H}_{2} \mathrm{PO}_{4}^{-}$has a detrimental effect on the 
microalgae growth. At the same time, at smaller values of anion $\mathrm{H}_{2} \mathrm{PO}_{4}^{-}$concentrations, there is an increase in the biomass of microalgae cells compared to the control. The main parameter is the value of the growth coefficients $-\mu$ which was determined according to the presented methodology Fig. 6. It should also be noted that in the experimental study, there is a change in the alkaline acid balance of the aquatic environment, namely from acidic $(\mathrm{pH}=4.7)$ to neutral $(\mathrm{pH}=6.8)$.

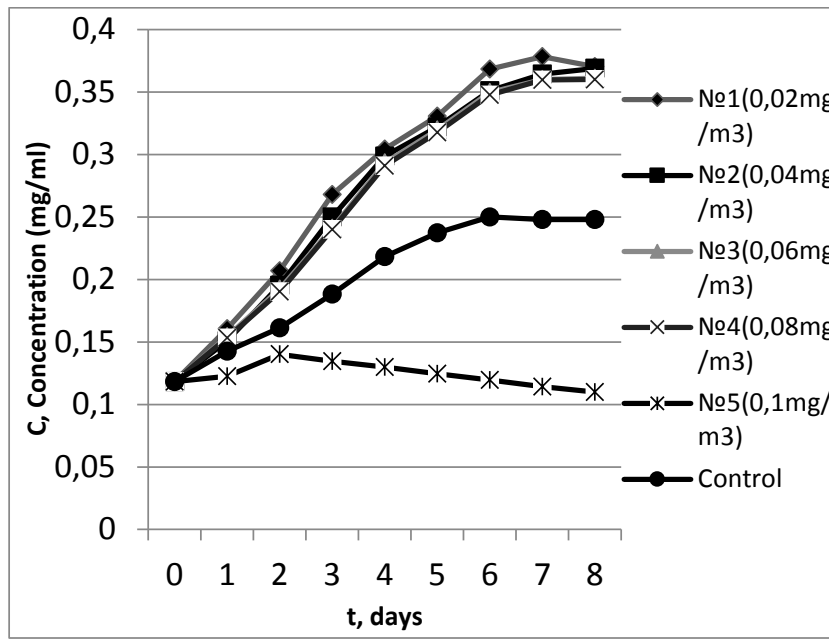

Fig. 5. The dependence of the change in the concentration of microalgae cells over time at the corresponding anion $\mathrm{H}_{2} \mathrm{PO}_{4}^{-}$concentrations

For the analytical calculation of the optimum values of anions concentrations in wastewater to be purified using chlorophyll synthesizing microalgae, a mathematical model of microalgae biomass growth depending on the concentration of the corresponding anions was created:

$$
\left\{\begin{array}{l}
\frac{d C}{d x}=\mu_{1} C-\mu_{2} C \\
\frac{d C}{d \mathrm{x}}=\mu_{1} C \\
x=0, C=C_{o}
\end{array}\right.
$$

where, $x$ is concentration of anions $\mathrm{HSO}_{3}^{-}, \mathrm{NO}_{3}^{-}$and $\mathrm{H}_{2} \mathrm{PO}_{4}^{-} ; \mu_{1}, \mu_{2}$ are growth coefficients at favorable and unfavorable values of anions $\mathrm{HSO}_{3}^{-}, \mathrm{NO}_{3}^{-}$and $\mathrm{H}_{2} \mathrm{PO}_{4}^{-}$

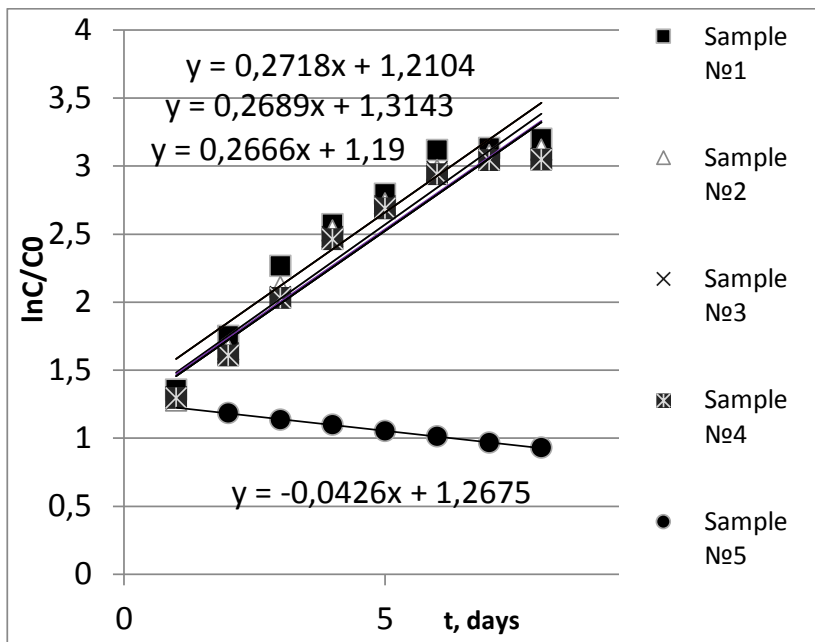

Fig. 6. Dependence of change in logarithm of suspension concentration of microalgae cells on time (at corresponding anion $\mathrm{H}_{2} \mathrm{PO}_{4}^{-}$) concentrations

concentration; $\mathrm{C}$ is the concentration of microalgae in the cultivation medium.

Its solutions have several analytical expressions. One of them allows you to calculate the critical values of the corresponding anion concentrations according to the known values of the growth coefficients $\mu$;

$$
x_{\max }=\frac{\ln \mu_{2}-\ln \mu_{1}}{\left(\mu_{1}+\mu_{2}\right)} ;
$$

Using the data of mathematical processing of the experimental study results of the microalgae biomass growth, the corresponding values of the growth coefficients were calculated $\mu_{1}, \mu_{2}$. After substituting the obtained values for the anions $\mathrm{NO}_{3}^{-}$and $\mathrm{H}_{2} \mathrm{PO}_{4}^{-}$in equation (2) we calculate the optimum value of anion $\mathrm{NO}_{3}^{-}$concentration in the cultivation medium:

$$
x_{\text {max }}=\frac{\ln \mu_{2}-\ln \mu_{1}}{\left(\mu_{1}+\mu_{2}\right)}=\frac{\ln (-0,037)-\ln 0,076}{(0,076-0,037)}=18,46 \mathrm{mg} / \mathrm{m}^{3}
$$

Similarly, using equation (2), we calculate the optimal value of anion $\mathrm{H}_{2} \mathrm{PO}_{4}^{-}$concentration in the cultivation medium:

$$
x_{\max }=\frac{\ln \mu_{2}-\ln \mu_{1}}{\left(\mu_{1}+\mu_{2}\right)}=\frac{\ln (-0,0426)-\ln 0,2425}{(0,2425-0,0426)}=0,061 \mathrm{mg} / \mathrm{m}^{3} ;
$$

According to the equations 3 and 4 , the concentration of anions $\mathrm{NO}_{3}^{-}$and $\mathrm{H}_{2} \mathrm{PO}_{4}^{-}$is determined at which the maximum value of the microalgae biomass concentration in the culture medium is reached. To check the adequacy of the mathematical model and its solution, we build graphs 
of the dependence of anions $\mathrm{NO}_{3}^{-}$and $\mathrm{H}_{2} \mathrm{PO}_{4}^{-}$ concentration on the growth coefficient $\mu$.

From (Figs. 7 and 8) it is seen that the maximum increase in the concentration of microalgae is achieved at the concentration of anion $\mathrm{NO}_{3}^{-}$ $\approx 18 \mathrm{Mg} / \mathrm{M}^{3}$ and anion $\mathrm{H}_{2} \mathrm{PO}_{4}^{-} \quad \approx 0,06 \mathrm{Mg} / \mathrm{M}^{3}$

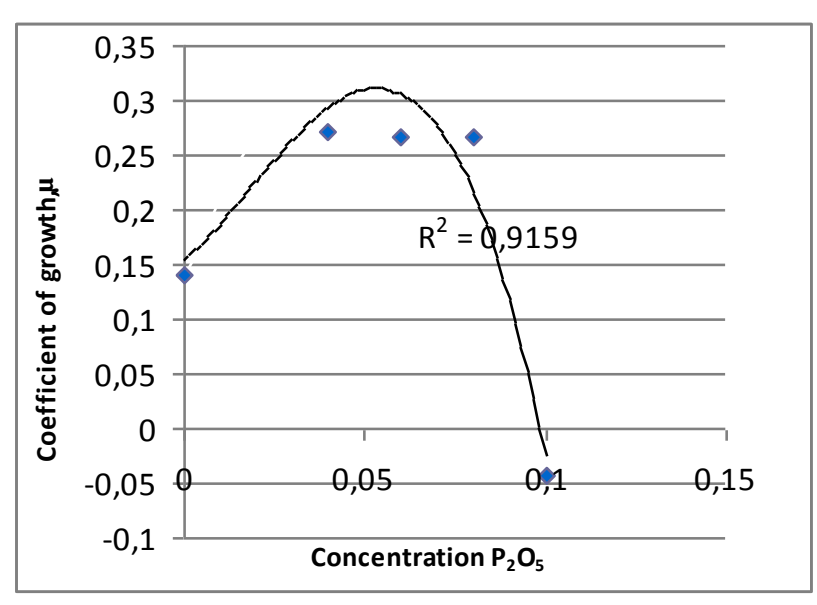

Fig. 7. Dependence of the microalgae growth coefficient $\mu$ on the concentration of anions $\mathrm{H}_{2} \mathrm{PO}_{4}^{-}$ concentration. This indicates that the mathematical model accurately describes the course of the study process, and the obtained solutions will allow us to predict equipment for the implementation of wastewater treatment technology under the presence of anions $\mathrm{NO}_{3}^{-}$та $\mathrm{H}_{2} \mathrm{PO}_{4}^{-}$(Fig. 9).

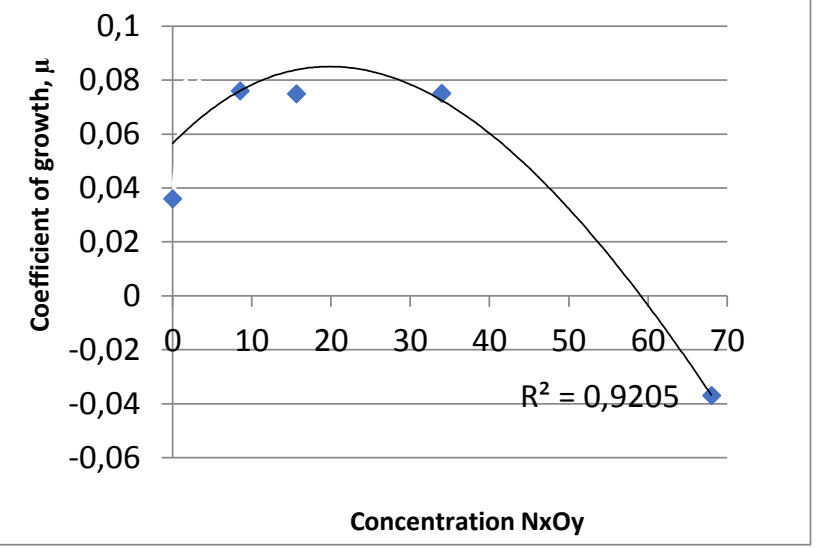

Fig. 8. Dependence of the microalgae growth coefficient $\mu$ on the concentration of anions $\mathrm{NO}_{3}^{-}$

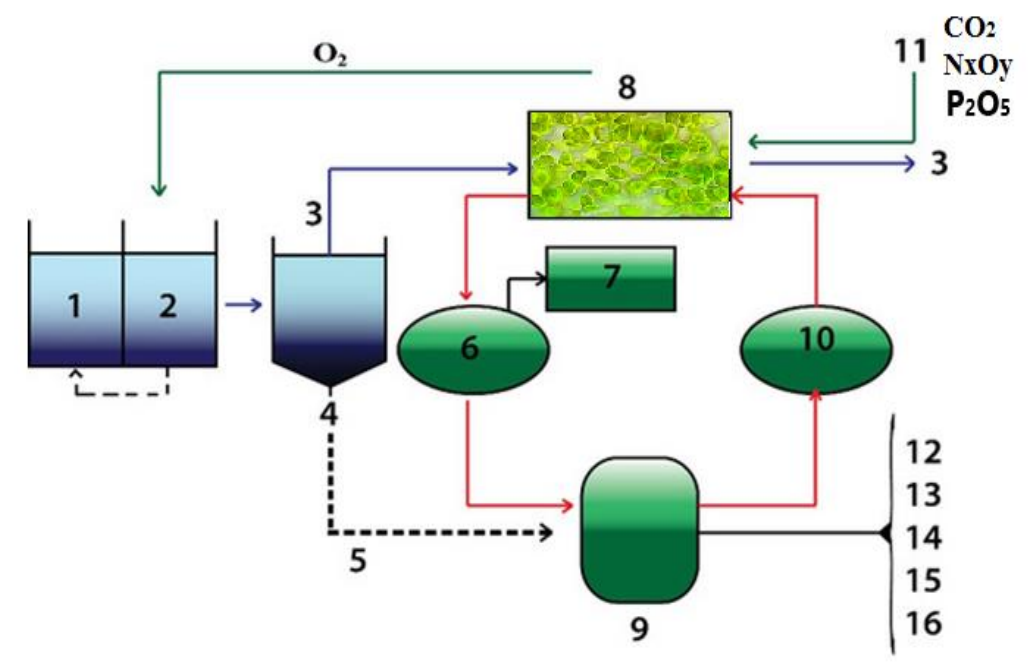

Fig. 9. Combined wastewater treatment scheme using Chlorella type microalgae.

1 - anoxide zone; 2 - oxide zone; 3 - wastewater after the process with activated sludge;

4 -secondary sedimentation tank; 5 - precipitate secondary sedimentation tank;

6 - microalgae biomass; 7 - tank; 8 - cultivation of the Chlorella type microalgae;

9 - hydrothermal liquefaction or anaerobic digestion; 10 - biogenes and $\mathrm{CO}_{2}$;

$11-\mathrm{CO}_{2}, \mathrm{P}_{2} \mathrm{O}_{5}$ and $\mathrm{NxOy}$ from other systems; 12 - biochar; 13 - protein/nutritional supplements; 14 - fertilizers; 15 - soil amendment; 16 - biofuels

Fig. 9 presents a scheme of wastewater treatment using the Chlorella type microalgae. The scheme consists of a biofilm reactor with a movable layer of nozzle for air bubbling 1 , and an open pond for the cultivation of microalgae as a biological reactor 2 . Wastewater after the process with activated sludge 3 , fall into the container 8 , where the cultivation of the Chlorella type microalgae happens. The wastewater sludge enters the secondary sedimentation tank 4 and from there the precipitate of the second sludge 5 enters the hydrothermal liquefaction or anaerobic digestion 9 . Since microalgae cultivation requires $\mathrm{CO}_{2}$, there is an opportunity to use its emission at the 
enterprises of other industries (for example, power plants), reducing the emission into the atmosphere. Therefore, $\mathrm{CO}_{2}$, $\mathrm{P}_{2} \mathrm{O}_{5}$ and $\mathrm{NxOy}$ from other systems 11 fall into the tank 8 for the cultivation of microalgae. From tank 8 , the biomass of microalgae enters tank 6 , from which it enters tank 9 for hydrothermal liquefaction or anaerobic digestion, or tank 7 where organic "green" fertilizer is made from it. From tank 9 biogenes and $\mathrm{CO}_{2}$ enter tank 10 , and from it again into tank 8 of microalgae cultivation. Everything else after hydrothermal liquefaction or anaerobic digestion 9 is also converted into fertilizers 14, protein or nutritional supplements 13, soil amendment 15, and biofuels 16 (Khlorella..., 2020).

\section{Conclusion}

Chlorella microalgae are the most appropriate option for wastewater treatment. They are also a promising substrate for biofuel production since obtaining biomass creates the potential for energy production.

Based on the results of the experimental research, mathematical models have been created that allow predicting the maximum values of anions $\mathrm{NO}_{3}^{-}$and $\mathrm{H}_{2} \mathrm{PO}_{4}^{-}$. concentrations and at which effective wastewater treatment with chlorophyll synthesizing microalgae is possible.

The result of wastewater treatment by this method is the change of alkaline acid balance from acidic to neutral after the experiment.

The scheme of wastewater treatment using chlorophyll synthesizing microalgae of the Chlorella type is proposed. Limit values of concentrations of anions $\mathrm{HSO}_{3}^{-}, \mathrm{NO}_{3}^{-}$and $\mathrm{H}_{2} \mathrm{PO}_{4}^{-}$are set for the successful operation of this treatment plant.

The use of the Chlorella type microalgae for wastewater treatment creates new opportunities for environmental safety improvement by designing and building a reliable system.

\section{References}

Dyachok, V., Huhlych, S., Yatchyshyn, Y., Zaporochets Y., \& Katysheva V. (2017). About the problem of biological processes complicated by mass transfer. Chemistry \& Chamical technology, 11(1), 111-116. doi: https://doi.org/ 10.23939/chcht11.01.111

Dyachok, V. V., \& Mandryk, S. T. (2018). Investigation of the influence of nitrogen oxides to increase chlorophyll synthesizing microalgae in aquatic environment. 8-th International Joint Youth Science Forum "Litteris et Artibus": Proceedings. (pp. 282-283). November 22-24, 2018, Lviv, Ukraine: Lviv Polytechnic National University.

Dyachok, V., Mandryk, S., Katysheva, V., \& Huhlych S. (2019a). Effect of fuel combustion products on carbon dioxide uptake dynamics of chlorophyll synthesizing microalgae. Journal of Ecological Engineering, 20(6), 1824. doi: https://doi.org/10.12911/22998993/108695

Dyachok, V., Mandryk, S., \& Huhlych, S. (2019b). Activator of carbon dioxide absorption by chlorophyll-synthesizing microalgae. Environmental Problems, 4(2), 63-67. doi: https://doi.org/10.23939/ep2019.02.063

Hubskyy, Yu. I. (2007). Biolohichna khimiya. Kyiv-Vinnytsia: Nova knyha. [in Ukraine]

Khlorella $v$ ochystke stochnykh vod. (2020). Retrieved from https://hlorella.jimdo.com/ [in Russian]

Manakov, M. N., \& Pobedimskiy, D. G. (1990). Teoreticheskie osnovyi tehnologii mikrobiologicheskih proizvodstv. Moscow: Agropromizdat. [in Russian]

Poltorak, O. M. \& Chuhray, O. S. (1972). Physico-chemical basis of enzymatic catalysis. Moscow: Visshaya shkola. [in Russian]

Statsenko, O. V. \& Vynohradova R. P. (1992). Bioorhanichna khimiya. Kyiv: Vyshcha shkola. [in Ukraine]

Zolotaryova, O. K., Shnyukova, Ye. I., Syvash, O. O., \& Mykhaylenko, N. F. (2008). Perspektyv vykorystannya mikrovodorostey u biotekhnolohii. Alholohiia, 19 (2), 234243. [in Ukraine] 